\title{
Preface: From orogenesis to geoscience in the service of society: the scientific legacy of Prof. Andrés Pérez-Estaún
}

\author{
Joaquina Alvarez-Marrón ${ }^{1}$, Fernando Bastida ${ }^{2}$, Ernest Rutter ${ }^{3}$, Ramon Carbonell $^{1}$, and Charlotte M. Krawczyk ${ }^{4}$ \\ ${ }^{1}$ Institute of Earth Sciences Jaume Almera, ICTJA-CSIC, Lluis Sole i Sabaris s/n, 08028 Barcelona, Spain \\ ${ }^{2}$ Department of Geology, University of Oviedo, Jesús Arias de Velasco s/n, 33005 Oviedo, Spain \\ ${ }^{3}$ Rock Deformation Laboratory, School of Earth and Environmental Sciences, University of Manchester, \\ Manchester M139PL, UK \\ ${ }^{4}$ Helmholtz Centre Potsdam, GFZ German Research Centre for Geosciences, Telegrafenberg 14473 Potsdam, Germany \\ Correspondence to: Joaquina Alvarez-Marrón (jalvarez@ictja.csic.es)
}

Received: 18 July 2016 - Published: 8 August 2016

\section{Biography of Prof. Andrés Pérez-Estaún}

This special issue is dedicated to the memory of our friend and colleague Prof. Andrés Pérez-Estaún, who passed away unexpectedly in August 2014 at the age of 67. He was known by everybody as Andrés, because he always insisted on being called by his first name. He was born in Jaca (Huesca) but he liked to be considered "Asturian" (from Asturias) because he moved to this region of Spain at the age of 18 to study geology at the University of Oviedo. Although he gained his degree in 1970, he had been teaching to younger undergraduates from a year before. Teaching was for him his most important professional endeavour. To it he showed devoted dedication and enthusiasm, and he was always available to meet the needs of his students. He taught in the classroom and in the field to more than 25 cohorts of undergraduate students, to whom he was able to transmit not only the factual knowledge of the discipline but also his passion to disentangle the message hidden in rocks. He also led field excursions to the NW Spain region for several groups of British students over a period of more than 15 years.

Andrés had started his PhD thesis work when in 1973 he enrolled at the Imperial College London, where he was awarded a diploma and master's degree in structural geology and rock mechanics with distinction in 1974. He was amongst the very few students that obtained that level of attainment. Back to Oviedo, he concentrated on finishing his thesis and obtained his $\mathrm{PhD}$ degree in 1975. His thesis comprised a field-based study of a large area of the West Asturian-Leonese Zone of the Variscan orogenic belt in NW

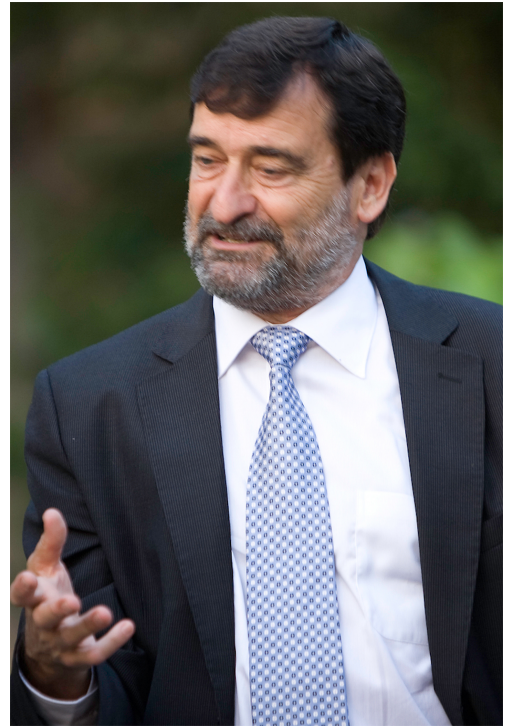

Figure 1. Prof. Andrés Pérez-Estaún.

Spain (Pérez-Estaún, 1978). In addition to unravelling general aspects of the area, such as the stratigraphy and metamorphism, he applied his recently gained expertise to the analysis of the structure. He actively and generously helped in the development of several $\mathrm{PhD}$ theses that were ongoing or had been initiated since his return from the UK, thus contributing to the rapid dissemination of his recently learned expertise in structural geology among his Spanish colleagues. He formally supervised eight $\mathrm{PhD}$ students from 1986 to 
1996, and their research mostly focused on the structure and tectonics of the Variscan orogen of NW Spain (see Supplement attached to this preface). Many of his students maintained close contact and friendship with him during their subsequent careers, of which Andrés was very proud. They always obtained a generous response whenever they sought his advice. With the years, they progressively became part of his extensive network of geology professionals, distributed throughout the Spanish research administration, academia and industry.

The specialization gained by Andrés at Imperial College had an extensive influence on the research developed subsequently by the structural geology team at the University of Oviedo. It permitted the inclusion of the then forefront techniques and methods into the group's research. In addition, Andrés and his colleagues from the structural geology group in Oviedo then initiated fruitful international relations mostly with geoscientists initially from the UK and later on from other countries. This opening up of the group contributed to the internationalization of research on the Variscan orogeny by Spanish geoscientists that benefitted from the numerous field trips that Andrés led for visitors to the region during most of the 1980s. The internationalization and opening of the structural geology group was reflected in the success of the International Conference on Plate Tectonics held in Gijón (Asturias) in 1987 that the group organized and of which Andrés was the coordinator.

An important milestone in the professional biography of Andrés was his determination and perseverance to obtain the funding for an ambitious seismic profiling experiment. The group had acquired a vast knowledge of the geology of northern Spain by the end of the 1980s, and he envisaged that it was time to go a step further. The experiment called ESCIN (Seismic Study of the Northern Iberian Crust) was finally realized. It included the acquisition between 1991 and 1993 of four deep seismic profiles together with other complementary geophysical data. The profiles were aimed at obtaining an image of the Variscan section through northern Spain that successfully corroborated many of the interpretations previously made from surface geological studies, but it also provided a new perspective on the Alpine deformation of the region.

Andrés's tireless dedication to teaching and research did not obscure his incessant concern with the improvement of working conditions and efficiency within the university and the research in the geosciences in Spain. The late 1970s to early 1980s were years of political transition in Spain, and Andrés participated actively in the movement of university teachers that sought structural changes and modernization of the Spanish universities. Later on, once new legislation started to take effect in Spanish universities in 1983, he held several administrative positions. He was vice-dean and dean of the faculty of geology from 1984 to 1989 , and secretary of the Institute of Applied Geology from 1986 to 1989. Andrés participated also in establishing a Geological Society of
Spain. The society was inaugurated in 1985 , of which he was a founding member. He was then vice-president (1989-1990) and president (1991-1993) of its tectonics group.

In 1994, Andrés was appointed to a research professor position in the Spanish National Research Council (CSIC) and moved to Barcelona to work at the Institute of Earth Sciences "Jaume Almera" (ICTJA). There, where he was dedicated to research full-time, his innate leadership capabilities flourished. He went on to be the leader and coordinator of large international programmes and projects that consisted of a multidisciplinary study of the Urals. Among them were projects financed by the European International Association for the promotion of cooperation with scientists from the independent states of the former Soviet Union (INTAS) and the URO TMR Network, which was financed by the EU Fourth Framework Programme. A total of 28 researchers from 7 institutions of 6 different EU countries working with their corresponding Russian collaborators participated in the URO Network. Andrés was also a key player in the implementation in the Urals of the ambitious seismic experiment URSEIS whose results appeared in four articles in the journal Science in 1996.

Andrés was convinced that the significant advance of the geosciences in Spain, founded upon the knowledge accumulated through the work of many research groups, which was mostly possible because of the availability of public funding since the emergence of democracy in Spain, should directly benefit society. To facilitate this, he was able to coordinate the work of scientists from a variety of disciplines to implement integrated multidisciplinary approaches to the highresolution characterization of the subsurface. These collaborations were intended to serve the needs of public or private organizations engaged in the construction of large infrastructure developments or the management of industrial residues or contaminants, such as nuclear waste or capture and storage of $\mathrm{CO}_{2}$. For example, he led important projects coordinated with ENRESA (the Spanish public body in charge of the management of nuclear waste) for the near-surface characterization of the subsurface in an old uranium mine, of the area for storage of low- and intermediate-level residue, and lately of the region selected to harbour the future Spanish centralized temporal storage site for nuclear waste. Since 2007, a major task for him was to establish a pilot site to apply and test combined techniques and methods for the underground storage of $\mathrm{CO}_{2}$. After an enormous dedication of effort, the Hontomin site was established in February 2012. It continues to be today a world-class pilot site to conduct research on the geological storage of $\mathrm{CO}_{2}$ in deep saline formations. He was the director of the programme concerning geological storage of $\mathrm{CO}_{2}$ for the Spanish Public Foundation CIUDEN between 2007 and 2013.

During his years at ICTJA, Andrés participated as an expert on numerous committees dealing with the supervision or management of research in and application of the Earth sciences in Spain. Among the most relevant were the Natu- 
ral Resources Commission of CSIC from 1994 to 1996 and the committee of the National Programme for Marine Science and Technology and the Antarctic (1997-1998). He participated in the commission that drafted the National Plan for Research Development and Innovation 2000-2003. He was member of the National Evaluation Commission in the Natural Resources area (1999-2000) and president of it in 2001. He was member of the Scientific Advisory Board of the Spanish Geological Survey (IGME) in 2001, and of the National Commission on Geology in 2003.

At an international level, Andrés also participated in significant advisory boards and expert committees. He served on the following panels:

(a) European Science Foundation Management Committee of the Ocean Drilling Programme, from 1992 to 1998 ,

(b) European Union Earth Science Panel of the Training and Mobility of Researchers Programme, from 1995 to 1998 ,

(c) Scientific Committee of the International Continental Drilling Program, from 1996 to 1999 ,

(d) French GeoFrance 3-D Programme, which is associated with the following French institutions: BRGM (Geological Survey), CNRS (National Center for Scientific Research), INSU (National Institute for the Sciences of the Universe of France) and the French Ministry of National Education, Higher Education and Research, from 1997 to 2000 ,

(e) Scientific Advisory Board of the European Union EUROPROBE programme from 1998 to 2001 ,

(f) Scientific Advisory Board of the Italian Istituto Nazionale di Oceanografia e Geofisica Sperimentale, in 2001,

(g) European Union project for cooperation in the mining sector (SYSMIN) in the Dominican Republic, from 1998 to 2004 ,

(h) Commission on Tectonics of the International Union of Geological Sciences, from 1998 to 2004.

In recognition of his accomplishments, the Royal Academy of Natural Physics and Exact Sciences of Spain made him a corresponding member in 2007. In 2008, he was made a corresponding member of the Academy of Sciences of the Dominican Republic. Through the years, Andrés became one of the best known and most highly respected geoscientists of Spain. A list of his scientific contributions is included in the Supplement attached to this preface.

\section{Highlights of Prof. Andrés Pérez-Estaún's lines of research}

The research and professional activities of Andrés in the field of Earth Sciences developed over a wide range of themes, scales and geological environments. He mastered a wide variety of methods and techniques. For the purpose of this special volume, we have grouped his research under two major topics. He conducted research on orogenesis throughout his whole career, becoming one of the best-respected experts on the Spanish Variscides and on the geology of the Iberian Peninsula. Later, he also studied in detail the Urals and the island of Hispaniola. Since the mid 1990s he conducted research on the topic that we call "Geosciences in the service of society". Here we provide a brief description of his achievements.

\subsection{Orogenesis}

Andrés gave great emphasis and dedicated much of his time during his early career to field-based studies. He contributed substantially to the $1: 50000$ and $1: 200000$ scale geological mapping across the Variscan belt in the NW Iberian Peninsula. This large production of maps resulted in significant advances in the understanding of the Variscan orogen, but it was also very significant in that the availability of maps fomented new applied research and mining exploration, and also benefitted the development of geoengineering of later large infrastructure projects.

His research on Variscan orogenesis provided new views and understanding of the kinematic evolution of the footwall to the suture of the orogen (Pérez-Estaún et al., 1991) and on the evolution of the Cantabrian Zone (Pérez-Estaún et al., 1988). His contribution in Tectonics in 1988 is one of his most cited papers and continues to be widely referenced today. He also provided new and modern interpretations for the hinterland structures and in particular for the AsturianLeonese Zone. He became one of the leading experts on the Spanish Variscides and was the coordinator of the section about the Iberian Massif in the modern compilation book about the geology of Spain published in 2004 (Pérez-Estaún and Bea, 2004).

The knowledge that stemmed from field-based studies in northern Spain opened new perspectives into the study of the crustal-scale orogenic structure. He led the seismic profiling project in the early 1990s that aimed at constraining the orogen's large-scale structural linkage at depth. The results of that project changed our perspective of the northern Iberian continental crust and its margin. Profile ESCIN-1 corroborated many of the previous interpretations on the structure of the Cantabrian Zone (Pérez-Estaún et al., 1994), and other profiles were paradigm makers for subsequent studies on the effects of Alpine deformation in northern Spain and its continental margin (Pulgar et al., 1996; Alvarez-Marrón et al., 1996). After that experience, Andrés went on with his am- 
bition of studying the Iberian crust and was a key player in the acquisition and interpretation of the IBERSEIS and ALCUDIA deep seismic profiles across southern areas of the Iberian Massif (Simancas et al., 2003; Martínez-Poyatos et al., 2012). The good quality images of the Iberian crust provided by the deep profiles, together with the extensive new knowledge and understanding of the geology that stemmed from them, resulted in an unprecedented well-constrained crustal-scale geological cross section of the entire Variscan orogen.

Andrés also extended his research on orogenesis to the study of other mountain belts. He dedicated more than 10 years to the study of the southern Urals and developed new collaborations that led to a large number of high-impact publications (i.e. Carbonell et al., 1996; Berzin et al., 1996). There, he played a leading role in the realization of the deep seismic reflection-profiling in the southern Urals (URSEIS). The section across the southern Urals is since then considered a type example of a Palaeozoic orogen with a wellpreserved arc-continent collision structure sandwiched by the collision of the eastern European and Eurasian continental land masses (Brown et al., 1998). His work there also involved the opening of the geology of the Urals to Western geoscientists.

More recently Andrés turned his attention to the study of the geology of the island of Hispaniola. There, he focused on the unravelling of the processes that are involved in active oblique arc-continent collision orogens (e.g. Escuder et al., 2007). His studies contributed greatly to a better understanding of the tectonics of this area of the Caribbean Plate.

\section{2 "Geosciences in the service of society"}

In parallel with his studies of orogenesis, and mostly since 1995, Andrés played a key role in leading the implementation of ambitious programmes undertaken by the Spanish administration to address societal challenges, such as the disposal of nuclear waste and the geological storage of $\mathrm{CO}_{2}$. This line of research evolved as a holistic approach to the characterization of the shallow subsurface, and with the years he was able to lead a large number of highly skilled researchers that used approaches from varied disciplines and techniques, not only from the geosciences, towards that single objective. Although the initial motivation was to deliver to society a greatly improved description of the shallow subsurface readily available for infrastructural and resource development, this research also had a fundamental focus on the development of methods and techniques to aid in the answering of geological questions.

In 1996, he initiated a study that aimed at the characterization of a network of fractures in a granitic substratum in order to understand the pathways that could cause contamination in the waters surrounded an abandoned uranium mine (Martí et al., 2002). That study contributed to the establishment of the initial core group of researchers led by Andrés that would acquire the expertise for subsequent studies on the characterization of the subsurface. For example, they undertook the geological characterization in El Cabril low- and intermediate-level residue storage site, the characterization of the subsurface along the new metro line 9 of the city of Barcelona (Martí et al., 2008; Font-Capo et al., 2011), the characterization of the subsurface along a sector of the underground operation for the high-speed train in northern León, and the most recent one that Andrés was leading for the temporal storage of nuclear waste in Villar de Cañas (Martí et al., 2015). However, during his latest years his main line of effort was on the geological sequestration of $\mathrm{CO}_{2}$. In this respect, he led a very ambitious project for establishing a Spanish pilot site for technology development of geological $\mathrm{CO}_{2}$ sequestration in saline deep aquifers (Alcalde et al., 2013; Ugalde et al., 2013). This site at Hontomin is now a reality and a large variety of experts continue to carry out research there. Some of the papers in this issue deal with some of their latest results.

\section{Special issue contents}

The papers included in this special issue have been solicited from colleagues that worked with Andrés and cover a large range of subject areas that reflect the wide range of research subjects that Andrés was concerned with. In some of them, Andrés appears as a co-author because they correspond to studies that he was developing before his untimely death.

Six papers of this special issue focus on studies of different aspects of orogenesis. From them, three focus on the Variscides of Iberia, two in the NW, and one in the SW sections. A fourth paper deals with the Alpine deformation of northern Iberia, and a fifth with the southern Urals, and the sixth is about the island of Hispaniola.

The paper by Fernández et al. focuses on the description of structures in the high-metamorphic-grade Masanteo gneisses in the Cabo Ortegal Complex and discusses the processes and deformation conditions during the exhumation from high-pressure conditions at the early stages of the Variscan orogeny in Iberia. The paper by Valín et al. presents the tectonothermal evolution of the area at the core of the Ibero-Armorican arc, in the Variscan orogen of NW Spain. They use several thermal indicators, such as the conodont colour alteration index (CAI), the Küber index of illite (KI), and the Árkai index of chlorite (AI), together with the analysis of clay minerals and cleavage in relation to the stratigraphy and structure. Andrés was a pioneer in the use of clay mineral analysis to determine the transition from diagenetic conditions to metamorphism in the NW Iberian Variscides. He applied it in his PhD thesis studies and collaborated with authors of this paper in the first decade of his research.

Authors Pérez-Cáceres et al. use simple monoclinic-flow models together with other tools to evaluate and approximately quantify the Variscan transpressional deformation in 


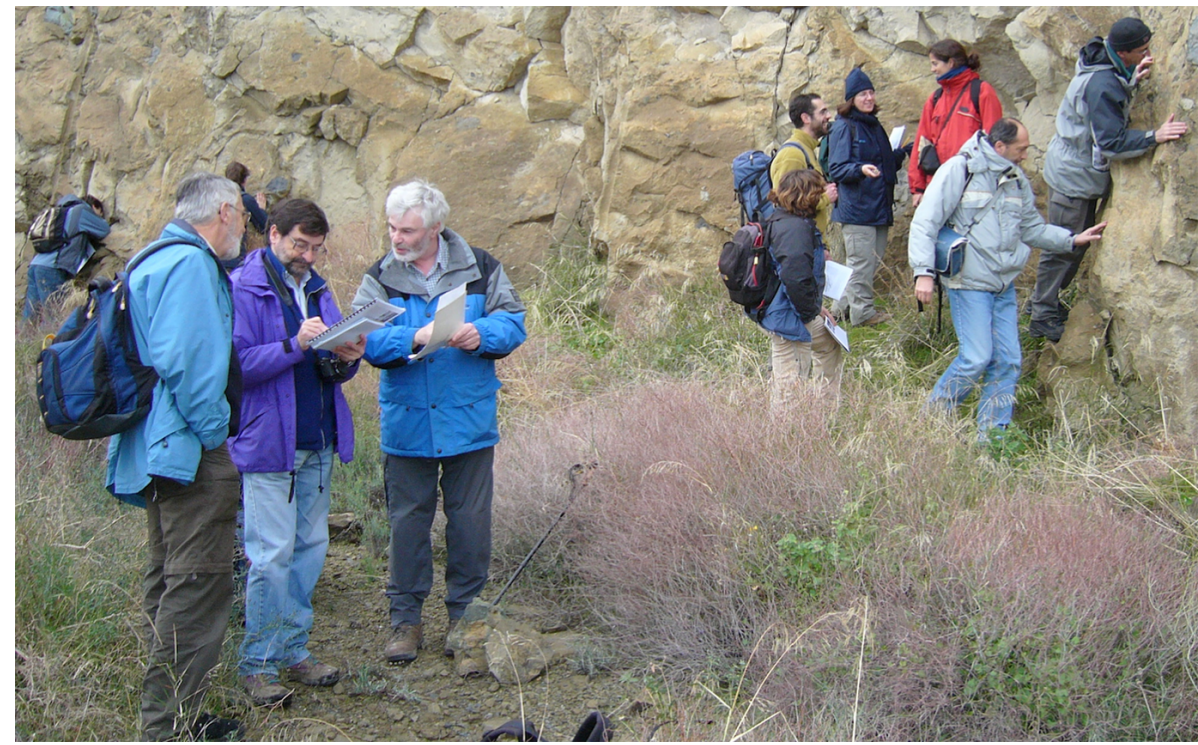

Figure 2. Prof. Andrés Pérez-Estaún in the field with participants in the UK Tectonic Studies Group field trip of 2006.

SW Iberia. From there, they go on to describe the deformation partitioning and kinematics along major tectonic boundaries in that Variscan section, and the implications for the palaeo-position of the involved terranes. They use an interpretation based on the IBERSEIS deep seismic profile as a basis for constructing a crustal-scale structural cross section. Some of the authors of this paper collaborated with Andrés during the implementation of the IBERSEIS profile and continue to show how that data may be the key to obtaining a deeper understanding of orogenic processes.

The paper by Gallastegui et al. uses one of the ESCIN deep seismic profiles, profile ESCIN-2 combined with gravity modelling and other geophysical data to provide an interpretation of the Alpine deformation in the Cantabrian Mountains and its foreland basin. The study is an example of how the ESCIN project led by Andrés from 1991 to 1993 ESCIN continues to stimulate studies on the crustal architecture of northern Spain.

In the paper by Puchkov there is a description of the main achievements obtained in the starting years of collaboration between Russian and Western scientists in the southern Urals. Those were the years of the EUROPROBE programme. The paper goes on to provide an update of the advances about the geology of the southern Urals since the end of that programme.

The paper by Escuder et al. presents results of the latest work by Prof. A. Pérez-Estaún and collaborators on the island of Hispaniola. The study undertakes a tectonostratigraphical analysis of sedimentary sequences that lie above an igneous and metamorphic basement. They combine that analysis with new ${ }^{40} \mathrm{Ar} /{ }^{39} \mathrm{Ar}$ chronological data from the basement, in order to determine the tectonic setting during basin formation and to unravel the exhumation history of the basement in relation to processes of arc-continent collision and ophiolite emplacement.

A further six papers of this special issue correspond to the topic of "Geosciences in the service of society" and focus on studies of high-resolution characterization of the subsurface. From them, four papers are related to studies about $\mathrm{CO}_{2}$ geological storage, three are about the subsurface characterization of the Hontomin pilot site, and one on $\mathrm{CO}_{2}$ injection. The fifth paper is about the hydrology of fractured granite in a mine, and the sixth is on the subsurface characterization of the urban area of Barcelona.

Ogaya et al. investigate how the combination of seismic reflection, well-log resistivity and magnetotelluric data from the Hontomin site may provide clues into the characterization of faults in the subsurface. It proposes empirical resistivityvelocity relationships to obtain local velocity models from resistivity (MT) data. From the results they discuss the possible incorporation of fluids in major faults. Andrés et al. present the results of studies in the Hontomin pilot site that had started in collaboration with Andrés before his untimely death. The study integrates 3-D seismic data and microgravity to constrain the structure of the top basement and the thickness of overlaying Keuper evaporites. The goal was to provide a consistent structural model of the site from the surface down to the basement. The paper by Benjumea et al. combines geophysical well logs and seismic ambient noise measurements to characterize near-surface downward velocity inversions due to hard rock (limestone) being underlain by soft rock (siliciclastic sediments). This case study at Hontomin combines measurements of sediment thicknesses with low-cost techniques that are useful for subsequent design of seismic reflection experiments and/or to aid in their processing (e.g. static corrections). The paper includes a repro- 
duction of an interpreted correlation of well-log data manually drafted by Prof. Andrés Pérez-Estaún. Berrezueta et al. present the results from experimental injection of supercritical $\mathrm{CO}_{2}$ into sandstone saturated and covered with brine. The study aimed at reproducing the reservoir rock dry-wet environment, adjacent to a theoretical injection borehole. They conclude that the chemical interaction of acidified brine and rock during injection may induce physical porosity variations resulting in a facilitation of further $\mathrm{CO}_{2}$ injection.

Andrés was collaborator and co-author in the study presented here by Martinez Landa et al. It consists of a case example test of the theoretical suitability of low-permeability fractured granite for the hosting of nuclear waste. They use an approach that combines structural geology and geophysical techniques together with hydro-chemical and hydraulic tests data to identify fractures that conduct most of the groundwater flow. A 3-D numerical model is then used to calibrate cross-hole tests and make predictions of long timescale pumping tests. They conclude that the low hydraulic conductivity and low aggressiveness of the sodium bicarbonate groundwater make this southern European granite appropriate for hosting nuclear waste.

Andrés was collaborating in the study of the subsurface geology of the city of Barcelona before his premature death. Here Vázquez-Suñé et al. present the geological model of the shallow subsurface of the city and surrounding areas. The model incorporates diverse historical data with modern, recently acquired geological, hydrogeological, and geophysical data. All data are integrated through an effective datamanagement tool within a GIS environment. The study proposes a methodology for data management that allows continuous update and will benefit future sustainable management of the urban groundwater.

Two final contributions correspond to colleagues with whom Andrés had a long standing relationship. Ernie Rutter was one of the teaching staff at Imperial College who taught Andrés about rock mechanics in the 1970s. The paper by Hackston and Rutter deals with the failure of sandstones under polyaxial stress conditions, how the simple MohrCoulomb concept may not be a sufficient criterion for rock failure description, and also shows that rock frictional properties may be influenced by changes in the relative magnitudes of principal stresses. Good friends and collaborators of Andrés since his studies in the Urals were C. Juhlin and David Gee from Uppsala University. Here Juhlin et al. present a study in the Scandinavian Caledonides based on interpretation of newly acquired seismic profiles that are linked to results of nearby borehole data. The $2.5 \mathrm{~km}$ deep COSC-1 scientific borehole was drilled as part of the Collisional Orogeny in the Scandinavian Caledonides (COSC) project, which is partly supported by the International Continental Scientific Drilling Program. They propose possible locations for a second deep borehole in the framework of the COSC project.

\section{The Supplement related to this article is available online at doi:10.5194/se-7-1199-2016-supplement.}

Acknowledgements. We would like to thank all authors and reviewers for making this special issue possible. Also, our thanks go to the editorial managers of Solid Earth for their assistance. Funding for this publication is acknowledged to project CGL2013-4377-P.

\section{References}

Alcalde, J., Marzán, I., Saura, E., Martí, D., Ayarza, P., Juhlin, C., Pérez-Estaún, A., and Carbonell, R.: 3D geological characterization of the Hontomin $\mathrm{CO}_{2}$ storage site, Spain: multidisciplinary approach from seismics, well-logging and regional data, Tectonophysics, 627, 6-25, 2013

Alvarez-Marrón, J., Pérez-Estaún, A., Dañobeitia, J. J., Pulgar, J. A., and ESCI-N Group: Seismic structure of the Northern Continental Margin of Spain from ESCIN deep seismic profiles, Tectonophysics, 264, 153-174, 1996.

Berzin, R., Oncken, O., Knapp, J. H., Peréz-Estaún, A., Hismatulin, T., Yunosov, N., and Lipillin, V.: Orogenic evolution of the Ural Mountains: Results from an Integrated Seismic Experiment, Science, 274, 220-221, 1996.

Brown, D., Juhlin, C., Alvarez-Marrón, J., Pérez-Estaún, A., and Oslianski, A.: Crustal-scale structure and evolution of an arccontinent collision zone in the southern Urals, Russia, Tectonics, 17, 158-171, 1998.

Carbonell, R., Pérez-Estaún, A., Gallart, J., Diaz, J., Kashubin, S., Mechie, J., Stadtlander, R., Schulze, A., Knapp, J. H., and Morozov, A.: Crustal root beneath the Urals: wide-angle seismic evidence, Science, 274, 222-224, 1996.

Escuder, J., Contreras, F., Stein, G., Urien, P., Joubert, M., PérezEstaún, A., Friedman, R., and Ullrich, T.: Magmatic relationships and ages between adakites, magnesian andesites and $\mathrm{Nb}$ enriched basalt-andesites from Hispaniola: Record of a major change in the caribbean island arc magma sources, Lithos, 99, 151-177, 2007.

Font-Capó, J., Vázquez-Suñé, E., Carrera, J., Martí, D., Carbonell, R., and Pérez-Estaún, A.: Groundwater inflow prediction in urban tunneling, Eng. Geol., 121, 46-54, 2011.

Martí, D., Carbonell, R., Tryggvason, A., Escuder-Viruete, J., and Pérez-Estaún, A.: Mapping brittle fracture zones in 3 dimensions: high resolution travel time seismic tomography in a granitic pluton, Geophys. J. Int., 149, 95-105, 2002.

Martí, D., Carbonell, R., Flecha, I., Palomeras, I., Font-Capó, J., Vázquez-Suñé, E., and Pérez-Estaún, A.: High-resolution seismic characterization in an urban area: subway tunnel construction in Barcelona, Spain, Geophysics, 73, 841-850, doi:10.1190/1.2832626, 2008.

Martí, D., Marzán, I., Sachsenhausen, J., Alvarez-Marrón, J., Cienfuegos, I., and Carbonell, R.: High-resolution seismic characterization of the shallow surface applied to civil engineering. Proceedings volume 77th EAGE Conference \& Exhibition 2015, Earth Science for Energy and Environment, 1-4 June, doi:10.3997/2214-4609.201413471, 2015. 
Martínez-Poyatos, D., Carbonell, R., Palomeras, I., Simancas, J. F., Ayarza, P., Martí, D., Azor, A., Jabaloy, A., González Cuadra, P., Tejero, R., Martín Parra, L. M., Matas, J., González-Lodeiro, F., Pérez-Estaún, A., García Lobón, J. L., and Mansilla, L.: Imaging the crustal structure of the Central Iberian Zone (Variscan Belt): The ALCUDIA deep seismic reflection transect, Tectonics, 31, TC3017, doi:10.1029/2011TC002995, 2012.

Pérez-Estaún, A.: Estratigrafía y estructura de la rama S. de la Zona Asturoccidental-Leonesa, Memorias del IGME 92, Madrid, 152 pp., 1978.

Pérez-Estaún, A., Bastida, F., Alonso, J. L., Marquínez, J., Aller, J., Alvarez-Marrón, J., Marcos, A., and Pulgar, J. A.: A thinskinned tectonics model for an arcuate fold and thrust belt: the Cantabrian Zone (Variscan Ibero-Armorican Arc), Tectonics, 7, 517-537, 1988

Pérez-Estaún, A., Martínez-Catalán, J. R., and Bastida, F.: Crustal thickening and deformation sequence in the football to the suture of the Variscan Belt of northwest Spain, Tectonophysics, 191, 243-253, 1991.

Pérez-Estaún, A., Pulgar, J. A., Banda, E., Alvarez-Marrón, J., and ESCI-N Research Team: Crustal structure of the external Variscides in NW Spain from deep seismic reflection profiling, Tectonophysics, 232, 91-118, 1994
Pérez-Estaún, A. and Bea, F.: Macizo Ibérico, in: Geología de España, edited by: Vera, J. A., SGE-IGME, Madrid, 21-230, ISBN 84-7840-546-1, 2004.

Pulgar, J., Gallart, J., Fernández-Viejo, G., Pérez-Estaún, A., Alvarez-Marrón, J., and ESCIN Group: Seismic image of the Cantabrian Mountains in the western extension of the Pyrenees from integrated ESCIN reflection and refraction data, Tectonophysics, 264, 1-20, 1996.

Simancas, J. F., Carbonell, R., González Lodeiro, F., Pérez-Estaún, A., Juhlin, C., Ayarza, P., Kashubin, A., Azor, A., Martínez Poyatos, D., Almodóvar, G. R., Pascual, Sáez, E., R., and Expósito, I.: Crustal Structure of the Transpressional Variscan Orogen of SW Iberia: The IBERSEIS Deep Seismic Reflection Profile, Tectonics, 22, 1062, doi:10.1029/2002TC001479, 2003.

Ugalde, A., Villaseñor, A., Gaite, B., Casquero, S., Martí, D., Calahorrano, A., Marzán, I., Carbonell, R., and Pérez-Estaún, A.: Passive Seismic Monitoring of an Experimental $\mathrm{CO}_{2}$ Geological Storage Site in Hontomín (Northern Spain), Seismol. Res. Lett., 84, 75-84, 2013. 